Original Article

\title{
PHYTOCHEMICAL STUDIES OF ENDOLICHENIC FUNGI ISOLATED FROM HYPOTRACHYNA INFIRMA (KUROK.) HALE
}

\author{
GOKILAVANI R. ${ }^{1}$, H. REHANA BANU ${ }^{2}$ \\ 1,2Department of Botany, PSGR Krishnammal College for Women, Peelamedu, Coimbatore 641004, Tamil Nadu, India \\ Email: gokilarangasamy228@gmail.com
}

Received: 08 Apr 2021, Revised and Accepted: 19 Jun 2021

\section{ABSTRACT}

Objective: The aim of this study is to investigate of phytopharmaceutical importance of endolichenic fungi isolated from Hypotrachyna infirma (Kurok.) Hale.

Methods: The lichen species were collected from Sholaiyar hills, Coimbatore and identified as Hypotrachyna infirma (Kurok.)Hale. From this lichen, 29 endolichenic fungi were isolated and 13 endolichenic fungi were identified. From the identified endolichenic fungi, 26 extracts were prepared by successive solvent extraction methods using Ethyl acetate and chloroform.

Results: The phytochemical study revealed the presence of important constituents like Alkaloids, Tannins, Carbohydrates, Phenols, Protein, Terpenoids, Steroids, Glycosides Flavonoids and Saponins. From the 13 endolichenic fungi, only 5 endolichenic fungi (Nigrospora oryzae (Berkand Broome)Petch, Geotrichum candidum Link, Scytalidium lignicola pesante, Aspergillus oryzae(Ahlb.) cohn, Aspergillus niger Gr.) have more constitutents. These 5 endolichenic fungi have good results in Quantitative analysis also.

Conclusion: Compared to ethyl acetate extracts Chloroform extracts showed very less concentration of the phytochemicals. From this study we conclutated Nigrospora oryzae (Berk and Broome) Petch gave the best results in both qualitative and quantitative compared to other endolichenic fungi.

Keywords: Hypotrachyna infirma, Endolichenic fungus, Ethyl acetate, Chloroform and phytochemical

(C) 2021 The Authors. Published by Innovare Academic Sciences Pvt Ltd. This is an open access article under the CC BY license (https://creativecommons.org/licenses/by/4.0/) DOI: https://dx.doi.org/10.22159/ijpps.2021v13i8.41730. Journal homepage: https://innovareacademics.in/journals/index.php/ijpps.

\section{INTRODUCTION}

Lichen is a stable self-supporting association of a mycobiont (fungus) and a photobiont (alga, also houses fungi as endophytes and these are generally termed as endolichenic fungi. The term 'endolichenic fungi' was coined by for the fungi that live inside lichen thalli without producing any disease symptoms [1]. Lichens are known to synthesize a variety of secondary metabolites having varied activity in response to external environmental conditions. The use of lichens in medicine is due to their secondary metabolites that are unique compared to those of higher plants. In the history of endophytic research, the year 1977 is an important landmark year, because of the discovery of endophytic fungus Epichloe coenophiala (Neotyphodium coenophialum) from Festuca arundinacea which is the cause of "fescue toxicosis" [2].

An important elevated proportion of fungal endophytes (80\%) manufacture secondary metabolites possessing biologically active compounds [3] that are synthesized via various metabolic pathways [4]. These secondary metabolites are to be owned to different structural groups i.e., aliphatics, alkaloids, cytochalasines, depsipeptides, furandiones, isocumarines, phenols, quinines, steroids, terpenoids and xanthones, have been commercially utilized for pharmaceutical, medical and agricultural purposes [4-14].

The endolichenic fungal species investigated till date for the isolation of bioactive secondary metabolites belong to several geographical locations. The estimated global lichen diversity is about 20,000 [15] from this only a small number of lichen species have been screened for harvesting the endolichenic fungi with the potential to offer bioactive metabolites. Therefore one can assume the magnitude of prospective lichen diversity which is waiting to be unveiled. The test for the analysis of phytochemical compounds bring up the way to determine therapeutic drugs progressively [16].

Many researches were undergone based on endophytic fungi but less investigation was made on endolichenic fungi and their bioactive compounds. The aim of this work is to identify and analyse the phytochemistry of endolichenic fungi with two different solvent extract.

\section{MATERIALS AND METHODS}

\section{Collection of lichen}

Lichen sample was collected from Sholaiyar, Valparai Hills, Coimbatore District, Tamilnadu. The lichen sample was identified by Dr. Sanjeeva Nayaka, Principal Scientist, CSIR-National Botanical Research Institute, Lucknow, India. The collected lichen material was identified as Hypotrachyna infirma (Kurok.) Hale. This lichen was deposited at CSIR-National Botanial Research Institute, Lucknow, India with the Voucher number 36008.

\section{Chemicals and reagents}

Chemicals and reagents Dextrose, Agar, Dimethyl sulphoxide, Sodium carbonate, Vanillin Chloroform, Ethyl acetate, gallic acid, Phosphomolybdic acid, Folin-ciocalteau reagent, Catechin, aluminium chloride, Sulphuric acid, Hydrogen peroxide, Sodium hypochloride ( $\mathrm{NaClO}$ ), Ethanol were purchased from Hi-media.

\section{Surface sterilization of lichen}

Different types of protocols are available for surface sterilization. For this study modified protocol of [17] was used.

Healthy-looking macro lichen thallus was washed in tap water to remove all debris. Then the lichen was subjected to repeated washing in double distilled water to remove bryophytes/mosses and all other visible contamination. After this the washed samples were subjected to chemical surface sterilization by dipping them in $30 \%$ Hydrogen peroxide $\left._{2} \mathrm{O}_{2}\right)$ for 30 seconds, followed by $4 \%$ Sodium hypochloride $(\mathrm{NaClO})$ for 30 seconds and finally immersing them in $75 \%$ ethanol for 30 seconds.

After the chemical surface sterilization, the samples were rinsed in sterile double distilled water twice and dried under aseptic conditions and were cut into small segments $(0.5 \mathrm{~cm} \times 0.5 \mathrm{~cm})$. 


\section{Isolation of endolichenic fungi}

The sterilized lichen samples were placed on petriplates containing Potato Dextrose Agar (PDA) media and sealed using parafilm.

These petriplates were incubated in the culture room at $25 \pm 1{ }^{\circ} \mathrm{C}$ until fungal growth was initiated. After initiation, the growing fungal mycelia tips were transferred to new PDA plates for obtaining pure culture. After $15 \mathrm{~d}$, those endophytes that had grown on the PDA media were identified based on the morphology at National Fungal Culture Collection of India (NFCCI)-A National Facility, Pune, India.

\section{Preliminary phytochemical studies of endolichenic fungi}

\section{Fungal extraction}

A fraction of fungal isolates was transferred into Potato Dextrose Broth (PDB) by aseptically scraping using an inoculation loop. The isolates were transferred into conical flasks containing the Potato Dextrose Broth. These conical flasks were incubated in room temperature over a period of time. After $28 \mathrm{~d}$, culture liquid was filtered with help of Whatman No. 1 filter paper. The filtrates were used for further phytochemical studies.

To the filtrate equal volume of solvents were added, mixed well for $10 \mathrm{~min}$ and kept for $5 \mathrm{~min}$. Till the two clear immiscible layers were formed. The upper layer of the solvent containing the extracted compounds was separated using separating funnel. Solvent was evaporated and the compound was dried using a rotary vacuum evaporator to yield the crude metabolite [18]. The crude extract was then dissolved in Dimethyl sulphoxide at $1 \mathrm{mg} / \mathrm{ml}$ of concentration and the extract was kept at $4{ }^{\circ} \mathrm{C}$.

\section{Qualitative chemical evaluation}

The different fungal filtrates thus obtained were qualitatively tested for the presence of the following phytochemical constituents. The ethyl acetate and chloroform extracts of 13 endolichenic fungi were subjected to preliminary phytochemical screening. All preliminary phytochemical study was carried using the methodologies of Auwal MS et al., Wilberforce JO., et al.,, Kumar Bargah R, De Silva GO et al., Pavithra S et al. [19-23] To test the presence of Tannins, Flavonoids, Steroids, Phenol, Terpenoids, Saponins, Carbohydrates, Glycosides, Protein.

\section{Quantitative chemical evaluation}

Based on the qualitative analysis, the quantitative study was carried out for Tannins, Flavonoids, Phenols, and saponins.

\section{Total tannin content}

Total tannin content was measured by Folin-Denis method [24] 50 $\mu \mathrm{l}$ of the extract was made up to $7.5 \mathrm{ml}$ by adding double distilled water. Then $0.5 \mathrm{ml}$ of Folin-Denis reagent and $1 \mathrm{ml}$ of sodium carbonate were mixed with it. Again, volume was made up to $10 \mathrm{ml}$ by adding double-distilled water. Absorption was recorded at 700 $\mathrm{nm}$ as the vanillin reagent will react with any phenols that have an un-substituted resorcinol or phlorglucinol nucleus and forms a coloured substitution product which is measured at $700 \mathrm{~nm}$.

\section{Total phenol content}

Total phenolics were quantified and expressed as gallic acid equivalents according to the method proposed by Singleton et al. [25]. About $3.9 \mathrm{ml}$ of distilled water and $0.5 \mathrm{ml}$ of Folin-ciocalteau reagent were added to $0.1 \mathrm{ml}$ of sample extract in a tube and incubated at room temperature for 3 min after which $2 \mathrm{ml}$ of $20 \%$ sodium carbonate was added to this and kept at boiling water bath for 1 minute. Phenols react with phosphomolybdic acid in the Folinciocalteau reagent in alkaline medium and produce a blue coloured complex (molybdenum blue) that can be estimated calorimetrically at $650 \mathrm{~nm}$.

\section{Total flavonoid content}

Total flavonoid content was measured by the aluminium chloride colorimetric method [26]. $1 \mathrm{ml}$ of extract and standard solution of catechin $(100 \mathrm{mg} / \mathrm{ml})$ was added to $10 \mathrm{ml}$ volumetric flask containing $4 \mathrm{ml}$ of distilled water. To this $0.3 \mathrm{ml}$ of $5 \%$ sodium nitrate was added. After $5 \mathrm{~min}, 0.3 \mathrm{ml}$ of $10 \%$ aluminium chloride was added. Then after 1 minute, $2 \mathrm{ml}$ of $1 \mathrm{M}$ sodium hydroxide was added and the total volume was made up to $10 \mathrm{ml}$ with distilled water. The solution was mixed and the absorbance was measured against prepared reagent blank at $510 \mathrm{~nm}$.

\section{Total saponin content}

The vanillin-sulphuric acid assay [27] for determining the TSC of sample materials is usually done by incubating $0.25 \mathrm{ml}$ of sample extracts, standards or reagent blank with $0.25 \mathrm{ml}$ of $8 \%(\mathrm{w} / \mathrm{v})$ vanillin in ethanol and $2.50 \mathrm{ml}$ of $72 \%(\mathrm{v} / \mathrm{v})$ sulphuric acid in water for $15 \mathrm{~min}$ at $60^{\circ} \mathrm{C}$ in a shaking water bath, with the standards and the reagent blank made up with the solvent used for extracting the plant samples (extraction solvent). After cooling in water at the ambient temperature for $5 \mathrm{~min}$, the absorbance of the standards and extracts are measured at $560 \mathrm{~nm}$ using a Cary 50 UV-VIS spectrophotometer (Agilent Technologies, Santa Clara, CA, USA) after zeroing it with the reagent blank. The TSC of the samples is then expressed in mg of standard equivalents per gram of plant sample (mg SE g-1).

\section{RESULTS}

In the present study, a total of 13 endolichenic fungi were isolated from the lichen species Hypotrachyna infirma (Kurok.)Hale. Phytochemical studies including qualitative (Tannins, Flavanoids, Saponins, Steriods, Carbohydrates, Glycosides, Alkaloids, Proteins and Phenols) and quantitative (Tannins, Flavonoids, Saponins and Phenols) were done in two solvents ethyl acetate and chloroform for the isolated endolichenic fungi. From these two solvents, ethyl acetate gave best result compared to chloroform. Based on the results obtained from the qualitative analysis, the quantitative analysis was carried out.

\section{Qualitative phytochemical screening}

Table 1 shows qualitative analysis of 13 endolichenic fungal extracts in two solvents (ethyl acetate and Chloroform). The results of the phytochemical analysis of ethyl acetate extracts of Geotrichum candidum Link, Scytalidium lignicola Pesante, Aspergillus niger Gr, Aspergillus oryzae(Ahlb.)cohn, Nigrospora oryzae(Berk and Broome) Petch have high content of tannin, flavonoids, saponin and phenols, less content of Terpenoids, Steriods, Carbohydrates, Glycosoids, alkaloids, proteins. But Terpenoids were absent in Aspergillus oryzae(Ahlb.) cohn, and Glycosoids was absent in Geotrichum candidum Link.

\section{Quantitative phytochemical screening}

Quantitative phytochemical analysis is performed in two solvents ethyl acetate and chloroform. Graph 1 to 13 showed the presence and the amount of certain phytochemicals in the fungal extracts.

Table 1: Preliminary phytochemical constituents of a fungus with two different extracts

\begin{tabular}{|c|c|c|c|c|c|c|c|c|c|c|c|c|c|c|c|c|c|c|c|c|}
\hline \multirow{2}{*}{$\begin{array}{l}\text { Fungal } \\
\text { cultures }\end{array}$} & \multicolumn{2}{|c|}{ Tannins } & \multicolumn{2}{|c|}{ Flavanoids } & \multicolumn{2}{|c|}{ Terpenoids } & \multicolumn{2}{|c|}{ Saponin } & \multicolumn{2}{|c|}{ Steriods } & \multicolumn{2}{|c|}{ Carbohydrates } & \multicolumn{2}{|c|}{ Glycosides } & \multicolumn{2}{|c|}{ Alkaloids } & \multicolumn{2}{|c|}{ Proteins } & \multicolumn{2}{|c|}{ Phenols } \\
\hline & $\begin{array}{l}\text { Eth } \\
\text { yl } \\
\text { ace } \\
\text { tate }\end{array}$ & $\begin{array}{l}\text { Chl } \\
\text { orof } \\
\text { orm }\end{array}$ & $\begin{array}{l}\text { Eth } \\
\text { yl } \\
\text { acet } \\
\text { ate }\end{array}$ & $\begin{array}{l}\text { Chlo } \\
\text { rofo } \\
\text { rm }\end{array}$ & $\begin{array}{l}\text { Eth } \\
\text { yl } \\
\text { acet } \\
\text { ate }\end{array}$ & $\begin{array}{l}\text { Chl } \\
\text { orof } \\
\text { orm }\end{array}$ & $\begin{array}{l}\text { Eth } \\
\text { yl } \\
\text { acet } \\
\text { ate } \\
\end{array}$ & $\begin{array}{l}\text { Chl } \\
\text { orof } \\
\text { orm } \\
\text { rm } \\
\end{array}$ & $\begin{array}{l}\text { Eth } \\
\text { yl } \\
\text { acet } \\
\text { ate }\end{array}$ & $\begin{array}{l}\text { Chl } \\
\text { orof } \\
\text { orm }\end{array}$ & $\begin{array}{l}\text { Ethyl } \\
\text { aceta } \\
\text { te }\end{array}$ & $\begin{array}{l}\text { Chlor } \\
\text { ofor } \\
\mathrm{m}\end{array}$ & $\begin{array}{l}\text { Eth } \\
\text { yl } \\
\text { acet } \\
\text { ate } \\
\end{array}$ & $\begin{array}{l}\text { Chl } \\
\text { orof } \\
\text { orm }\end{array}$ & $\begin{array}{l}\text { Ethyl } \\
\text { aceta } \\
\text { te }\end{array}$ & $\begin{array}{l}\text { Chl } \\
\text { orof } \\
\text { orm }\end{array}$ & $\begin{array}{l}\text { Ethyl } \\
\text { aceta } \\
\text { te }\end{array}$ & $\begin{array}{l}\text { Chl } \\
\text { oro } \\
\text { for } \\
\text { m }\end{array}$ & $\begin{array}{l}\text { Eth } \\
\text { yl } \\
\text { acet } \\
\text { ate } \\
\end{array}$ & $\begin{array}{l}\text { Ch } \\
\text { orc } \\
\text { for } \\
\text { m } \\
\end{array}$ \\
\hline $\begin{array}{l}\text { Trichoderma } \\
\text { piluliferum J. }\end{array}$ & + & - & ++ & - & - & - & - & - & - & - & + & - & - & - & - & - & - & - & ++ & - \\
\hline $\begin{array}{l}\text { Trichoderma } \\
\text { harzianum } \\
\text { Rifai. }\end{array}$ & - & - & + & - & - & - & + & - & - & - & + & - & - & - & + & + & & & & - \\
\hline Scytalidium & +++ & - & t++ & - & + & - & +++ & - & ++ & - & ++ & - & + & - & + & & ++ & - & +++ & - \\
\hline
\end{tabular}




\begin{tabular}{|c|c|c|c|c|c|c|c|c|c|c|c|c|c|c|c|c|c|c|c|c|}
\hline $\begin{array}{l}\text { lignicola } \\
\text { Pesante }\end{array}$ & & & & & & & & & & & & & & & & & & & & \\
\hline $\begin{array}{l}\text { Geotrichum } \\
\text { candidum } \\
\text { Link }\end{array}$ & +++ & - & +++ & - & + & - & +++ & - & + & - & ++ & - & - & - & ++ & + & + & - & ++ & - \\
\hline $\begin{array}{l}\text { Aspergillus } \\
\text { stellatus } \\
\text { Curzi }\end{array}$ & +++ & - & + & - & ++ & - & ++ & - & ++ & - & ++ & - & ++ & - & ++ & - & ++ & - & +++ & - \\
\hline $\begin{array}{l}\text { Aspergillus } \\
\text { niger } \mathrm{Gr}\end{array}$ & +++ & - & +++ & - & + & - & ++ & - & + & - & + & - & + & - & + & - & + & - & - & - \\
\hline $\begin{array}{l}\text { Aspergillus } \\
\text { oryzae } \\
\text { (Ahlb.) Cohn }\end{array}$ & +++ & - & +++ & - & - & - & +++ & - & + & - & + & - & + & - & - & - & + & - & +++ & - \\
\hline $\begin{array}{l}\text { Aspergillus } \\
\text { flavus Link }\end{array}$ & - & - & + & - & & - & - & - & + & - & + & - & + & - & - & - & - & - & & - \\
\hline $\begin{array}{l}\text { Nigrospora } \\
\text { oryzae (Berk } \\
\text { and Broome) } \\
\text { Petch }\end{array}$ & +++ & - & +++ & - & + & - & +++ & - & + & - & + & - & ++ & - & ++ & - & + & - & +++ & - \\
\hline $\begin{array}{l}\text { Nodulisporiu } \\
\text { m gregarium } \\
\text { (Berk,andM. } \\
\text { A. Curtis) J. A. } \\
\text { Mey\# }\end{array}$ & ++ & - & + & - & + & - & + & - & + & - & + & - & + & - & + & - & + & - & ++ & - \\
\hline $\begin{array}{l}\text { Microascus } \\
\text { cirrosus } \\
\text { Curzi\# }\end{array}$ & + & - & ++ & - & - & - & + & - & - & - & + & - & + & - & - & - & - & - & + & - \\
\hline Trichoderma & - & - & + & - & + & - & - & - & + & - & - & - & + & - & + & - & + & - & + & - \\
\hline $\begin{array}{l}\text { sp., } \\
\text { Mucor sp. }\end{array}$ & + & - & + & - & + & - & ++ & - & - & - & - & - & - & - & + & - & + & - & + & - \\
\hline
\end{tabular}

Note: +++: Strong intensity reaction, ++: Medium intensity reaction,+: Weak intensity reaction, -: Non detected

Table 2: Quantitative phytochemical analysis of endolichenic fungi

\begin{tabular}{|c|c|c|c|c|c|c|c|c|}
\hline \multirow[t]{2}{*}{ Fungal cultures } & \multicolumn{2}{|l|}{ Tannins } & \multicolumn{2}{|l|}{ Flavonoids } & \multicolumn{2}{|l|}{ Saponins } & \multicolumn{2}{|l|}{ Phenols } \\
\hline & $\begin{array}{l}\text { Ethyl acetate } \\
\text { (mg) }\end{array}$ & $\begin{array}{l}\text { Chloroform } \\
\text { (mg) }\end{array}$ & $\begin{array}{l}\text { Ethyl acetate } \\
\text { (mg) }\end{array}$ & $\begin{array}{l}\text { Chloroform } \\
\text { (mg) }\end{array}$ & $\begin{array}{l}\text { Ethyl acetate } \\
\text { (mg) }\end{array}$ & $\begin{array}{l}\text { Chloroform } \\
\text { (mg) }\end{array}$ & $\begin{array}{l}\text { Ethyl acetate } \\
\text { (mg) }\end{array}$ & $\begin{array}{l}\text { Chloroform } \\
\text { (mg) }\end{array}$ \\
\hline Trichoderma piluliferum J. & $7.67 \pm 0.27$ & $5.23 \pm 0.10$ & $4.70 \pm 0.08$ & $3.07 \pm 0.10$ & $4.77 \pm 0.01$ & $1.53 \pm 0.07$ & $6.40 \pm 0.16$ & $4.13 \pm 0.05$ \\
\hline Trichoderma harzianum Rifai. & $8.23 \pm 0.11$ & $4.63 \pm 0.11$ & $5.63 \pm 0.14$ & $4.53 \pm 0.01$ & $2.23 \pm 0.01$ & $2.30 \pm 0.00$ & $3.40 \pm 0.12$ & $2.57 \pm 0.01$ \\
\hline Scytalidium lignicola pesante & $10.53 \pm 0.39$ & $7.37 \pm 0.11$ & $7.37 \pm 0.11$ & $5.10 \pm 0.08$ & $5.40 \pm 0.12$ & $3.40 \pm 0.04$ & $22.77 \pm 0.01$ & $17.23 \pm 0.14$ \\
\hline Geotrichum candidum Link & $17.77 \pm 0.10$ & $14.23 \pm 0.10$ & $9.63 \pm 0.07$ & $7.40 \pm 0.16$ & $3.17 \pm 0.10$ & $3.07 \pm 0.01$ & $26.97 \pm 0.19$ & $20.60 \pm 0.24$ \\
\hline Aspergillus stellatus curzi & $7.77 \pm 0.30$ & $5.07 \pm 0.10$ & $4.17 \pm 0.07$ & $2.20 \pm 0.08$ & $4.67 \pm 0.05$ & $2.67 \pm 0.07$ & $13.20 \pm 0.08$ & $8.03 \pm 0.10$ \\
\hline Aspergillus niger $\mathrm{Gr}$ & $14.57 \pm 0.15$ & $11.90 \pm 0.16$ & $6.30 \pm 0.12$ & $4.23 \pm 0.10$ & $9.13 \pm 0.11$ & $3.77 \pm 0.05$ & $13.87 \pm 0.27$ & $6.07 \pm 0.07$ \\
\hline $\begin{array}{l}\text { Aspergillus oryzae } \\
\text { (Ahlb.)cohn }\end{array}$ & $16.00 \pm 0.08$ & $13.47 \pm 0.19$ & $8.30 \pm 0.08$ & $4.97 \pm 0.11$ & $8.43 \pm 0.07$ & $4.37 \pm 0.05$ & $12.10 \pm 0.08$ & $5.73 \pm 0.18$ \\
\hline Aspergillus flavus link & $10.83 \pm 1.56$ & $10.80 \pm 0.12$ & $5.53 \pm 0.18$ & $2.57 \pm 0.14$ & $5.47 \pm 0.07$ & $2.20 \pm 0.04$ & $8.27 \pm 0.11$ & $4.00 \pm 0.04$ \\
\hline $\begin{array}{l}\text { Nigrospora oryzae (Berk and } \\
\text { Broome)Petch }\end{array}$ & $30.20 \pm 0.78$ & $22.10 \pm 0.12$ & $14.50 \pm 0.08$ & $9.23 \pm 0.03$ & $17.63 \pm 0.01$ & $12.67 \pm 0.07$ & $30.13 \pm 0.01$ & $19.67 \pm 0.23$ \\
\hline $\begin{array}{l}\text { Nodulisporium gregarium } \\
\text { Berk,andM. A. Curtis)J. A. Mey }\end{array}$ & $6.77 \pm 0.23$ & $5.40 \pm 0.16$ & $6.07 \pm 0.03$ & $4.73 \pm 0.07$ & $4.23 \pm 0.14$ & $2.67 \pm 0.05$ & $8.47 \pm 0.19$ & $6.73 \pm 0.11$ \\
\hline Microascus cirrosus Curzi\# & $5.80 \pm 0.12$ & $3.70 \pm 0.08$ & $5.53 \pm 0.14$ & $2.37 \pm 0.10$ & $6.53 \pm 0.03$ & $1.47 \pm 0.05$ & $7.17 \pm 0.11$ & $3.23 \pm 0.10$ \\
\hline Trichoderma sp., & $8.80 \pm 0.08$ & $6.27 \pm 0.11$ & $3.27 \pm 0.03$ & $2.13 \pm 0.01$ & $2.43 \pm 0.14$ & $1.20 \pm 0.08$ & $5.00 \pm 0.04$ & $2.47 \pm 0.03$ \\
\hline Mucor sp. & $7.53 \pm 0.07$ & $5.47 \pm 0.18$ & $4.63 \pm 0.11$ & $1.33 \pm 0.01$ & $3.43 \pm 0.05$ & $0.97 \pm 0.00$ & $3.70 \pm 0.08$ & $2.07 \pm 0.10$ \\
\hline
\end{tabular}

\#mean \pm SE Mean in a column followed by a same letter (s) are not significantly $(\mathrm{P}>0.05)$ different according to Duncan's Multiple Range Test **, *** Significant at $\mathrm{P}<0.01, \mathrm{P}<0.001$ respectively; ns-non significant

Maximum amount of tannin present in the ethyl acetate extract of Nigrospora oryzae (Berk and Broome)Petch $(30.20 \pm 0.78 \mathrm{mg} / \mathrm{ml}$ ), Geotrichum candidum Link $(17.77 \pm 0.10 \mathrm{mg} / \mathrm{ml})$, Aspergillus oryzae(Ahlb.)cohn $(16.00 \pm 0.08 \mathrm{mg} / \mathrm{ml})$.

Maximum content of phenols present in the ethylacetate extract of Nigrospora oryzae (Berk and Broome)Petch(30.13 $\pm 0.01 \mathrm{mg} / \mathrm{ml}$ ), Geotrichum candidum Link $(26.97 \pm 0.19 \mathrm{mg} / \mathrm{ml})$, Scytalidium lignicola pesante $(22.77 \pm 0.01 \mathrm{mg} / \mathrm{ml})$.

High amount of flavonoids present in the ethyl acetate extract of Nigrospora oryzae (Berk and Broome)Petch $(14.50 \pm 0.08 \mathrm{mg} / \mathrm{ml})$, Geotrichum candidum Link $(9.63 \pm 0.07 \mathrm{mg} / \mathrm{ml})$, Aspergillus oryzae(Ahlb.)cohn $(8.30 \pm 0.08 \mathrm{mg} / \mathrm{ml})$.

Maximum amount of saponin present in the ethyl acetate extract of Nigrospora oryzae (Berk and Broome) Petch $(17.63 \pm 0.01 \mathrm{mg} / \mathrm{ml}$ ), Aspergillus niger $\mathrm{Gr}(9.13 \pm 0.11 \mathrm{mg} / \mathrm{ml})$, Aspergillus oryzae(Ahlb.) cohn $(8.43 \pm 0.07 \mathrm{mg} / \mathrm{ml})$.

\section{DISCUSSION}

The secondary metabolites are different in various organic extracts of all the fungal culture. Their qualitative analysis revealed their appearance whereas their quantitative analysis give almost approximate idea for their quantity present Endolichenic fungi were discovered when attempts were being made to isolate the lichen forming mycobiont into pure culture [28, 29]. These fungi are similar to the endophytic fungi (sometimes also referred to as endophyte-like fungi) $[30,31]$, which reside within healthy tissues of plants and are phylogenetically and ecologically diverse without causing any disease symptoms $[32,33]$.

The overlap between endolichenic and endophytic metabolites is consistent with their biological similarities; there exists considerable overlap in the taxa represented in endolichenic and endophytic fungal strains, and they are believed to perform similar ecological roles for the host organism [34]. However, endolichenic fungal metabolites remain relatively distinct from the natural products produced by lichens individually $[35,36]$.

In the living systems, alkaloids are most significant compounds that play a metabolic role and are involved in the protective function in animals. Nigrospora oryzae (Berkand Broome) Petch and Geotrichum candidum (Berkand Broome) Petch gave good results. The results showed the high amount of Flavonoids and phenols present in Nigrospora oryzae(Berkand Broome) Petch $>$ Geotrichum candidum 
Link $>$ Scytalidium lignicola pesante $>$ Aspergillus oryzae (Ahlb.) cohn $>$ Aspergillus niger Gr. Flavonoids inhibits the promotion of growth and progression of tumors and also used against the cancercausing tumors [37]. In plants phenols when mixed with the flavonoid compounds it show multiple activities like antioxidant, anticarcinogenic, anti-inflammatory, etc. [38]. Singh and Bhat (2003) [39] studied flavonoids are responsible for the antimicrobial activity associated with some ethno medicinal plants.

The presence of tannins in extracts inhibits the pathogenic fungi and showed better antimicrobial activity [40]. The presence of tannins in diets for livestock have been showed to have antinutritional and toxic effects including fed intake, growth, feed efficiency and net metabolizable energy [41]. Nigrospora oryzae (Berk and Broome) Petch contain high amount of tannin compared to the other endolichenic fungus.

The natural compounds have an effective dosage response and minimum side effects when compared to synthetic compounds. The plant screened for phytochemical constituents seemed to have the potential function as a source of beneficial drugs and also to improve the health status of the consumers as a result of the presence of various compounds that are vital for good health [42].

\section{CONCLUSION}

From this study Nigrospora oryzae (Berk and Broome) Petch gave the best results in both qualitative and quantitative compared to other endolichenic fungi. Geotrichum candidum (Berkand Broome) Petch, Scytalidium lignicola Pesante gave the moderate results. Aspergillus niger $\mathrm{Gr}$, Aspergillus oryzae (Ahlb.)cohn gave less results compared to other organisms. Based on the phytochemical studies, further research can be carried out to isolate the particular phytochemical compounds in the endolichenic fungi.

\section{ACKNOWLEDGMENT}

The authors like to express our gratitude towards UGC grant Commission, New Delhi, and the management of PSGR Krishnammal College for Women, Coimbatore for providing the facility to carry out the research.

\section{FUNDING}

Nil

\section{AUTHORS CONTRIBUTIONS}

All authors' contributions are equal.

\section{CONFLICT OF INTERESTS}

The authors declare that there is no conflict of interests regarding the publication of this paper.

\section{REFERENCES}

1. Miadlikowska J, Arnold A, Lutzoni F. Diversity of cryptic fungi inhabiting healthy lichen thalli in a temperate and tropical forest. Ecol Soc Am Annu Meet 2004;89:349-50.

2. Bacon CW, Porter JK, Robbins JD, Luttrell ES. Epichloe typhina from toxic tall fescue grasses. Appl Environ Microbiol 1977;34:576-81.

3. Schulz B, Boyle C, Draeger S, Rommert AK, Krohn K. Endophytic fungi: a source of novel biologically active secondary metabolites. Mycol Res 2002;106:996-1004.

4. Tan RX, Zou WX. Endophytes: a rich source of functional metabolites. Nat Prod Rep 2001;18:448-59.

5. Castillo UF, Strobel GA, Ford EJ, Hess WM, Porter H, Jensen JB, et al. Wide-spectrum antibiotics produced by streptomyces NRRL 30562, endophytic on Kennedia nigriscansaa the GenBank accession number for the sequence determined in this work is AY127079. Microbiology 2002;148:2675-85.

6. Castillo U, Harper JK, Strobel GA, Sears J, Alesi K, Ford E, et al. Kakadumycins, novel antibiotics from Streptomyces sp. NRRL 30566, an endophyte of Grevillea pteridifolia. FEMS Microbiol Lett 2003;224:183-90.

7. Strobel G, Daisy B. Bioprospecting for microbial endophytes and their natural products. Microbiol Mol Biol Rev 2003; 67:491-502.
8. Ezra D, Hess WM, Strobel GA. New endophytic isolates of muscodor albus, a volatile-antibiotic-producing fungus. Microbiology 2004;150:4023-31.

9. Li H, Qing C, Zhang Y, Zhao Z. Screening for endophytic fungi with antitumour and antifungal activities from Chinese medicinal plants. World J Microbiol Biotechnol 2005;21:1515-9.

10. Park JH, Choi GJ, Lee SW, Lee HB, Kim KM, Jung HS, et al. Griseofulvin from Xylaria sp. strain F0010, an endophytic fungus of Abies holophylla and its antifungal activity against plant pathogenic fungi. J Microbiol Biotechnol 2005;15:112-7.

11. Gunatilaka AL. Natural products from plant-associated microorganisms: distribution, structural diversity, bioactivity, and implications of their occurrence. J Nat Prod 2006;69:509-26.

12. Wang FW, Jiao RH, Cheng AB, Tan SH, Song YC. Antimicrobial potentials of endophytic fungi residing in Quercus variabilis and brefeldin a obtained from Cladosporium sp. World J Microbiol Biotechnol 2007;23:79-83.

13. Priti V, Ramesha BT, Singh S, Ravikanth G, Ganeshaiah KN, Suryanarayanan TS, et al. How promising are endophytic fungi as alternative sources of plant secondary metabolites? Curr Sci 2009;97:477-8.

14. You F, Han T, Wu JZ, Huang BK, Qin LP. Antifungal secondary metabolites from endophytic Verticillium sp. Biochem Syst Ecol 2009;37:162-5.

15. Feuerer T, Hawksworth DL. Biodiversity of lichens, including a worldwide analysis of checklist data based on Takhtajan's floristic regions. Biodivers Conserv 2007;16:85-98.

16. Thamaraikani V, Sekar T. Assessment of phytochemicals and in vitro antioxidant, the anti-inflammatory activity of sarcostemma brunonianum wight and arn. Int J Curr Pharm Res 2021;13:64-9.

17. Suryanarayanan TS, Thirunavukkarasu N, Hariharan GN, Balaji P. Occurrence of non-obligate microfungi inside lichen thalli. Sydowia Horn 2005;57:120.

18. Bhardwaj A, Sharma D, Jadon N, Agrawal PK. Antimicrobial and phytochemical screening of endophytic fungi isolated from spikes of Pinus roxburghii. Arch Clin Microbiol 2015;6:1-9.

19. Auwal MS, Saka S, Mairiga IA, Sanda KA, Shuaibu A, Ibrahim A. Preliminary phytochemical and elemental analysis of aqueous and fractionated pod extracts of Acacia nilotica (Thorn mimosa). In: Veterinary research forum: an international quarterly journal. Faculty of Veterinary Medicine, Urmia University, Urmia, Iran; 2014.

20. Wilberforce JO, Olivia EI. Phytochemical screening and antimicrobial activity of leaves extracts of Mangifera indica and Carica papaya. Int J Curr Microbiol Appl Sci 2017;6:3253-9.

21. kumar Bargah R. Preliminary test of phytochemical screening of crude ethanolic and aqueous extract of Moringa pterygosperma gaertn. J Pharmacogn Phytochem 2015;4:7-9.

22. De Silva GO, Abeysundara AT, Aponso MM. Extraction methods, qualitative and quantitative techniques for screening of phytochemicals from plants. Am J Essent Oil 2017;5:29-32.

23. Pavithra S, Sekar T. Preliminary screening of phytochemical constituents, antioxidant, and antibacterial activities in the methanolic leaf extract of Meliosma simplicifolia (L.). Asian J Pharm Clin Res 2021;14:100-4.

24. Oyaizu M. Studies on products of browning reaction antioxidative activities of products of browning reaction prepared from glucosamine. Japan J Nutr Diet 1986;44:307-15.

25. Singleton VL, Orthofer R, Lamuela Raventos RM. Analysis of total phenols and other oxidation substrates and antioxidants by means of Folin-ciocalteu reagent. Meth Enzymol 1999; 299:152-78.

26. Zhishen J, Mengcheng T, Jianming W. The determination of flavonoid contents in mulberry and their scavenging effects on superoxide radicals. Food Chem 1999;64:555-9.

27. V Le A, E Parks S, H Nguyen M, D Roach P. Improving the vanillin-sulphuric acid method for quantifying total saponins. Technologies 2018;6:84.

28. McDonald TR, Gaya E, Lutzoni F. Twenty-five cultures of lichenizing fungi available for experimental studies on symbiotic systems. Symbiosis 2013;59:165-71.

29. Petrini O, Hake U, Dreyfuss MM. An analysis of fungal communities isolated from fruticose lichens. Mycologia 1990;82:444-51. 
30. Arnold AE, Miadlikowska J, Higgins KL, Sarvate SD, Gugger P, Way A, et al. A phylogenetic estimation of trophic transition networks for ascomycetous fungi: are lichens cradles of symbiotrophic fungal diversification? Syst Biol 2009;58:283-97.

31. U'Ren JM, Miadlikowska J, Zimmerman NB, Lutzoni F, Stajich JE, Arnold AE. Contributions of North American endophytes to the phylogeny, ecology, and taxonomy of Xylariaceae (Sordariomycetes, Ascomycota). Mol Phylogenet Evol 2016; 98:210-32.

32. Arnold AE, Maynard Z, Gilbert GS. Fungal endophytes in neotropical trees: abundance, diversity, and ecological implications. Tropical ecosystems: structure, diversity and human welfare. New Delhi: Oxford and IBH; 2001. p. 739-43.

33. Petrini 0. Fungal endophytes of tree leaves. In: Microbial ecology of leaves. Springer, New York, NY; 1991. p. 179-97.

34. Boustie J, Tomasi S, Grube M. Bioactive lichen metabolites: alpine habitats as an untapped source. Phytochem Rev 2011;10:287-307.

35. Romagni JG, Dayan FE. Structural diversity of lichen metabolites and their potential use. In: Advances in microbial toxin research and its biotechnological exploitation. Springer, Boston, MA; 2002. p. 151-69.
36. Shukla V, Joshi GP, Rawat MS. Lichens as a potential natural source of bioactive compounds: a review. Phytochem Rev 2010;9:303-14.

37. Tsuzuki JK, Svidzinski TI, Shinobu CS, Silva LF, Rodrigues Filho E, Cortez DA, et al. Antifungal activity of the extracts and saponins from Sapindus saponaria L. An Acad Bras Cienc 2007;79:577-83.

38. Kale AA, Torane RC, Deshpande NR, Salvekar JP. Antioxidant potential from stem bark of Juglans regia L. Ann Biol Res 2011;2:176-80

39. Zablotowicz RM, Hoagland RE, Wagner SC. Effect of saponins on the growth and activity of rhizosphere bacteria. In: Saponins used in food and agriculture. Springer, Boston, MA; 1996. p. 83-95.

40. Singh B, Bhat TK, Singh B. Potential therapeutic applications of some antinutritional plant secondary metabolites. J Agric Food Chem 2003;51:5579-97.

41. Acamovic T, Brooker JD. Biochemistry of plant secondary metabolites and their effects in animals. Proc Nutr Soc 2005;64:403-12.

42. Mir MA, Sawhney SS, Jassal MM. Qualitative and quantitative analysis of phytochemicals of Taraxacum officinale. J Pharm Pharmacol 2013;2:1-5. 